\title{
СОДЕРЖАНИЕ Ni И СИ В МИНЕРАЛЬНЫХ ОБРАЗОВАНИЯХ ПРИРОДНОГО И ТЕХНОГЕННОГО ГЕНЕЗИСА В ДОННЫХ ОТЛОЖЕНИЯХ ОЗЕРА НЮДЪЯВР (МУРМАНСКАЯ ОБЛАСТЬ)
}

Слуковский 3.И. ${ }^{1}$, Даувальтер В.А. ${ }^{2}$

${ }^{1}$ Институт геологии КарНЦ РАН, Петрозаводск, slukovskii_z@igkrc.ru

${ }^{2}$ Институт проблем промьшиенной экологии Севера КНЦ РАН, Anamumbl, vladimir@inep.ksc.ru

Тяжелые металлы (ТМ) - опасные загрязнители окружающей среды. Широкое распространение ТМ и их аккумуляция в различных компонентах природы (почвах, донных отложениях (ДО), живых организмах) тесно связана с развитием промышленности, ростом городских территорий и другими факторами. В зависимости от интенсивности и длительности антропогенной нагрузки территории, загрязненные ТМ, могут быть отнесены к зонам экологического риска, кризиса или бедствия. Примеры таких территорий можно найти в Северо-Западном регионе Российской Федерации.

Мурманская область - это промышленно развитый регион России, на территории которого находятся крупные предприятия, деятельность которых связана с разработкой месторождений медно-никелевых сульфидных руд и их дальнейшей переработкой. Одно из таких предприятий находится вблизи г. Мончегорска. Здесь располагается мощная производственная площадка Кольской ГМК, на которой перерабатывают медно-никелевый файнштейн, поступающий из городов Никеля и Заполярного, а также привозной файнштейн филиала ОАО «ГМК «Норильский никель» [3]. В то же время указанные предприятия являются основными загрязнителями окружающей среды, формируя специфические геохимические аномалии некоторых химических элементов (например, $\mathrm{Ni}, \mathrm{Cu}, \mathrm{S}$ ) в поверхностных водах, почвах, ДО водных объектов [2]. Отмечается, что в некоторых водоемах, расположенных в непосредственной близости от источников выбросов $\mathrm{TM}$, содержание $\mathrm{Ni}$ и $\mathrm{Cu}$ в верхних слоях ДО может достигать уровня макроэлементов [1].

Примером такого водоема является оз. Нюдъявр, которое вследствие длительной антропогенной нагрузки превратилось в техногенно-модифицированный объект, утративший свои природные свойства. Установлено, что загрязнение озера происходит как вследствие прямого поступления сточных и рудничных вод, так и в результате миграции загрязняющих веществ с территории водосбора и ремобилизации из осадков. Основное накопление $\mathrm{Ni}$ и Сu в ДО оз. Нюдъявр приходится на верхние 12 см (рис. 1). При этом наибольшие концентрации этих ТМ приходятся на среднюю часть указанной толщи озерных осадков - глубину ДО от 3 до 6 см для Cu и от 3 до 8 см - для Ni. Известно, что в избыточных количествах оба указанных химических элемента весьма токсичны для живых организмов, в том числе для гидробионтов.

Изучение образцов проб ДО оз. Нюдъявр осуществлялось при помощи сканирующего электронного микроскопа (СЭМ) VEGA II LSH с энергодисперсионным микроанализатором INCA En-
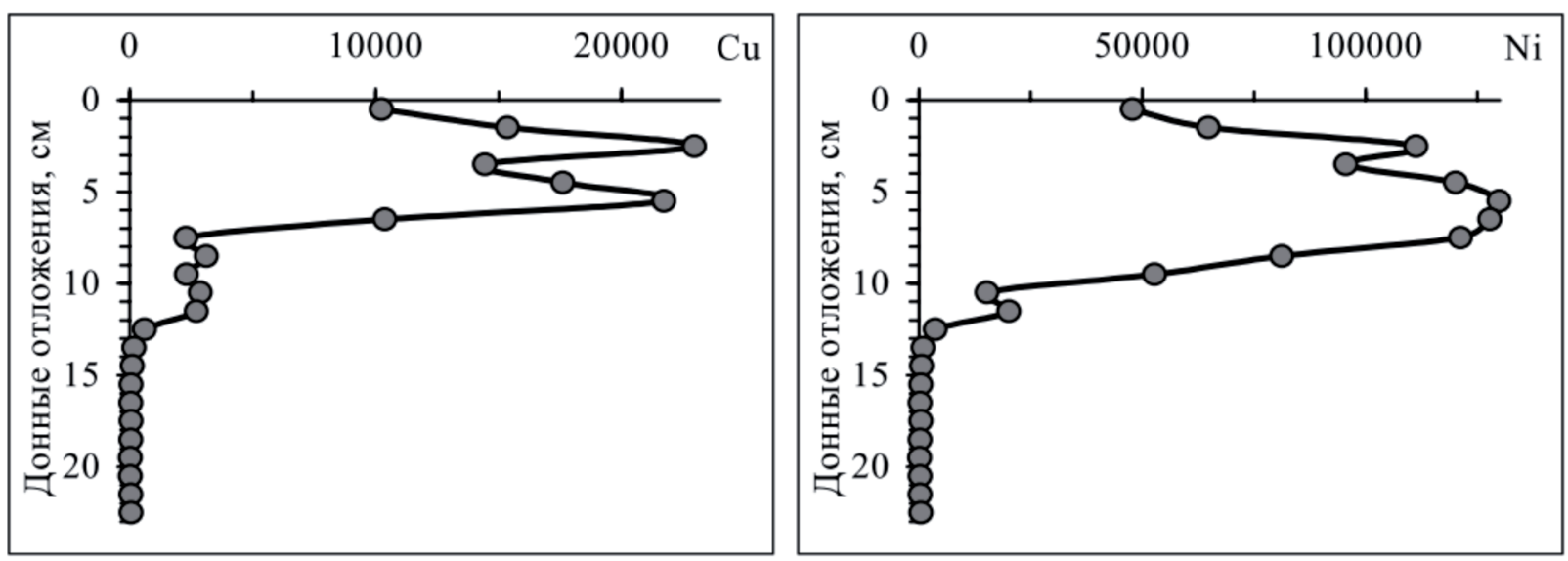

Рис. 1. Вертикальное распределение меди и никеля в колонке ДО оз. Нюдъявр [1]. 

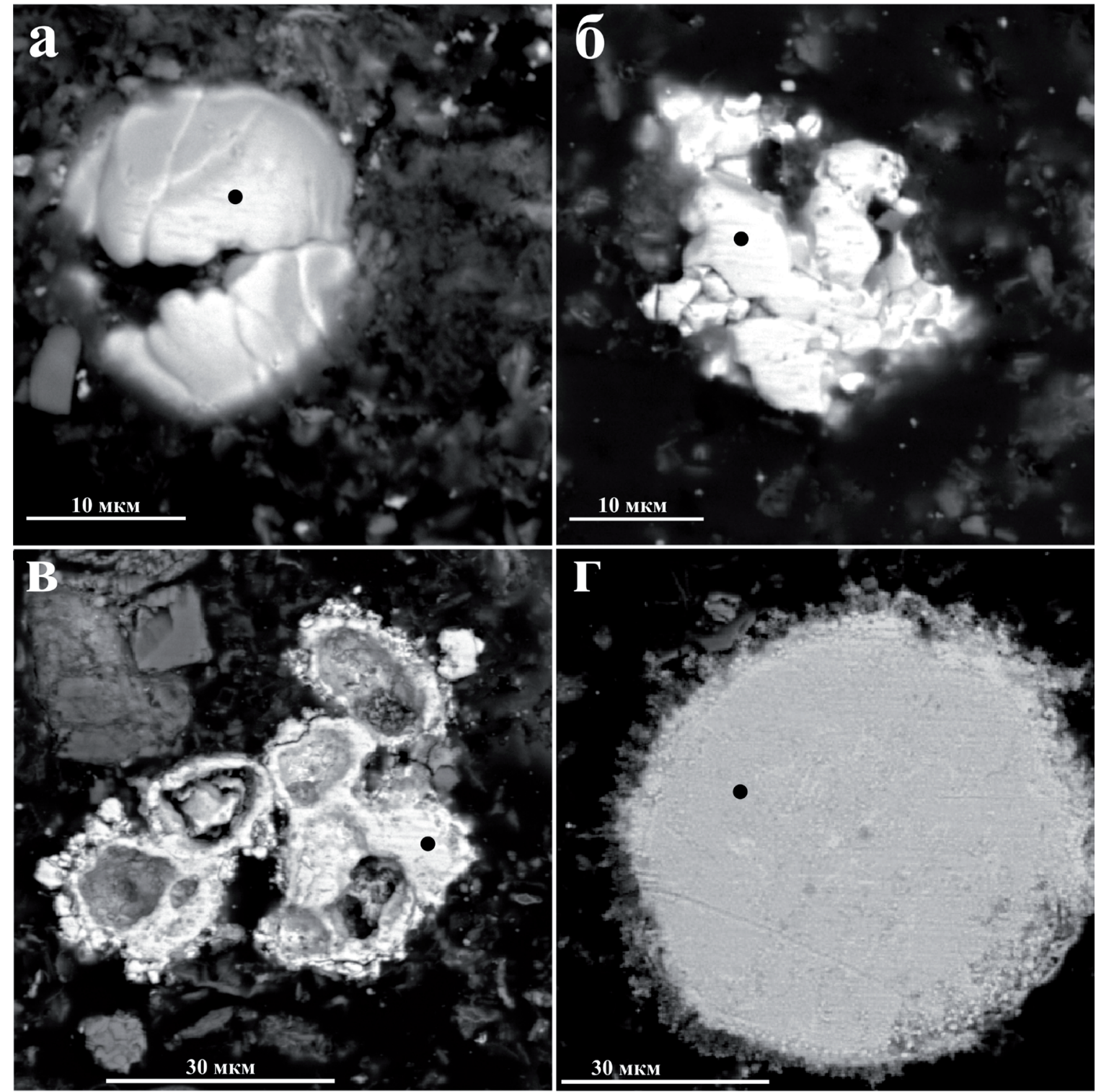

Рис. 2. Минеральные частицы техногенного генезиса в ДО (слой 6-7 см) оз. Нюдъявр (химический состав частиц представлен на рис. 3).

ergy 350 на базе аналитической лаборатории Института геологии Карельского научного центра РАН (Петрозаводск). Важным методическим моментом при изучении образцов проб стало увеличение времени набора спектра в точках анализа до 600 секунд (вместо «стандартных» 60-90), что определило относительно положительный результат проведенных исследований [5]. Были исследованы пробы ДО с четырех различных глубин: 0-1, 5-6, 6-7 и 11-12 см.

Среди 24 минеральных агрегатов исследованных в ходе работ были идентифицированы частицы округлой или неправильной форм, имеющих явное техногенное происхождение (рис. 2). Наибольшее количество этих частиц было обнаружено в слое 6-7 см ДО оз. Нюдъявр. В 7 частицах установлено содержание Ni от 29 до 69 вес. \%. В 5 минеральных агрегатах выявлено содержание $\mathrm{Cu}$ до 51.1 вес. \%. Изученные агрегаты имеют большие размеры (от 20 до 80 мкм) по сравнению с исследованными частицами в других слоях ДО оз. Нюдъявр. Очевидно, что эти минеральные частицы имеют генезис, связанный с промышленной переработкой руд цветных металлов.

В слоях 0-1 и 5-6 см также обнаружены подобные частицы с содержанием в них Ni от 55 до $94 \%$ и Сu от 4.0 до 76 \%. В самом нижнем слое ДО 11-12 см такие частицы выявлены в минимальном количестве. В состав изученных минеральных образований также входят $\mathrm{Fe}, \mathrm{S}, \mathrm{Cr}, \mathrm{Co}, \mathrm{Si}$ и O. 


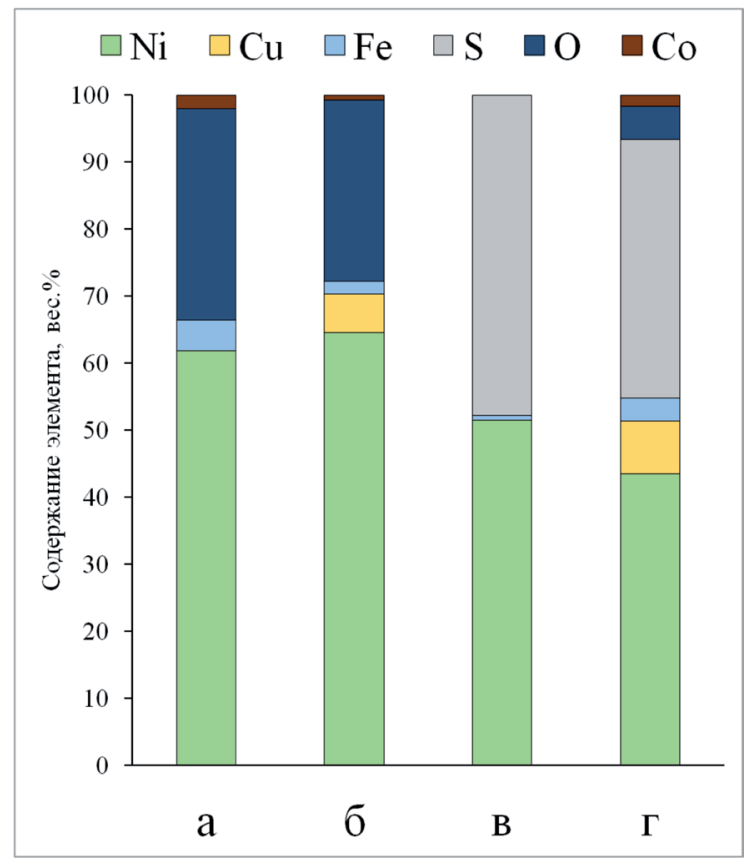

Рис. 3. Слой 6-7 см оз. Нюдъявр (обозначения «а», «б», «в» и «г» соответствуют аналогичным обозначениям на рис. 2).
Стоит также отметить, что во всех изученных образцах ДО встречаются частицы, похожие на агрегаты пирита разных стадий (сфероида, глобулы). Установлено, что размер этих сфероида и глобулы минеральных агрегатов ДО оз. Нюдъявр соответствуют полученным ранее размерам агрегатов пирита в ДО оз. Иманда [4]. В некоторых из этих частиц установлена примесь $\mathrm{Ni}$ и $\mathrm{Cu}$, которые, вероятно, были адсорбированы природным минеральным образованием железа. Следовательно, в исследованных ДО обнаружены две формы нахождения главных загрязняющих ТМ - в собственных минералах техногенного происхождения и в природных минералах в качестве примесей. Во втором случае содержание $\mathrm{Ni}$ и $\mathrm{Cu}$ во много раз ниже, чем в первом.

Таким образом, получены свидетельства того, что обогащение ДО оз. Нюдъявр (рис. 3) Ni, Cu и другими ТМ происходит за счет прямых выбросов промышленных предприятий непосредственно в водный объект и определенная доля концентраций загрязнителей связана с минеральными фазами, являющимися продуктами переработки руд цветных металлов. Исследование образцов проб ДО о3. Нюдъявр под электронным микроскопом позволило установить, что максимальное количество частиц техногенного генезиса приходится на время наиболее активных выбросов от медно-никелевого комбината. При этом выявлено, что исследованные ТМ могут присутствовать в минералах природного происхождения (пирит) в качестве примесей, что иллюстрирует значительную роль минералов железа в процессе миграции загрязнителей в водных объектах антропогенно нарушенной среды.

Исследование выполнено при финансовой поддержке РФФИ в рамках научного проекта № 18-05-00897.

\section{Литература}

1. Даувальтер В.А., Кашулин Н.А. Эколого-экономическая оценка необходимости извлечения донных отложений оз. Нюдъявр Мончегорского района Мурманской области // Вестник МГТУ. 2011. Т. 14 . № 4. C. 884-891.

2. Кашулин Н.А., Даувальтер В.А., Кашулина Т.Г., Сандимиров С.С., Раткин Н.Е., Кудрявцева Л.П., Королева И.М., Вандыш О.И., Мокротоварова О.И. Антропогенные изменения лотических экосистем Мурманской области. Ч. 1. Ковдорский район. Апатиты: Изд-во КНЦ РАН. 2005. 234 с.

3. Мончегорск / Норникель. ПАО «ГМК Норильский никель» [Электронный ресурc]. URL: http://www. kolagmk.ru/monchegorsk (дата обращения 10.06.2017).

4. Нерадовский Ю.Н., Даувальтер В.А., Савченко Е.Э. Генезис фрамбоидального пирита в современных осадках озер (Кольский п-ов) // Зап. РМО. 2009. Ч. СXXXVIII. № 6. С. 50-55.

5. Слуковский 3.И., Даувальтер В.А. Использование сканирующего электронного микроскопа в экологогеохимических исследованиях донных отложений водоемов Севера России // Тр. Ферсмановской научной сессии ГИ КНЦ РАН. 2017. № 14. С. 166-169. 